\title{
Liv på tvären: \\ Regnbågsbarns berättelser
}

\begin{abstract}
Nordén, Per. 2018. Regnbågsungar: Familj, utbildning, fritid. Avhandling. Göteborgs universitet: Institutionen för pedagogik, kommunikation och lärande. (239 sidor)
\end{abstract}

PER NORDÉNS AVHANDLING Regnbågsungar: Familj, utbildning, fritid inleds med ett citat från Ruffa Alving Ohlin, som växte upp under I900-talets mitt med två mammor, varav den ena var den kända reportern Barbro Alving, Bang. Alving Ohlin, som gick under skandalnamnet "Bang-barn", beskriver en uppväxt fylld av kärlek och trygghet. "Aldrig att jag förstod att det skulle vara något märkvärdigt", skriver hon efter att modern dött. "För mig kändes det fullt naturligt, bara något att avundas." (i Nordén 2018, I5)

Ruffa Alving Ohlins beskrivning av sin barndom illustrerar avhandlingens huvudsakliga fokus, att ge plats åt berättelser från barn som växer upp med föräldrar som lever på tvärs med heteronormen. Men citatet aktualiserar också den historiska förändring som avhandlingen utgår från, där rättigheter för både hbtq-föräldrar och deras barn - möjligheter att få vara förälder, få ha en förälder, få inseminera, adoptera, ja, att helt enkelt ha en statligt legitimerad föräldra-barnrelation - inte erhållits förrän runt sekelskiftet 2000 .

Det är heller ingen slump att begreppet regnbågsbarn inte började användas mer allmänt förrän just i början av 200o-talet, när regnbågsfamiljer i olika form börjar omskrivas som en ny västerländsk familje- 
form. Denna "gayby-boom" innebär i sin tur att regnbågsbarn som vuxit upp under vad Nordén kallar den "illegala tiden" (innan samkönade par var juridiskt likställda heterosexuella) blir mindre synliga eller riskerar att osynliggöras.

Nordéns studie tar avstamp i just dessa barns erfarenheter. Han har intervjuat 28 personer, mellan 15 och 37 år gamla, som vuxit upp med föräldrar som antingen är bi-, homosexuella eller transpersoner. Merparten har levt i heterosexuella kärnfamiljer som under deras uppväxt ombildats i och med att den ena föräldern kommit ut. I andra fall har familjerna kommit till genom heminsemination, vänskapsband eller utlandsadoption.

I fokus står alltså de numera vuxna "regnbågsbarnens" egna upplevelser av sin uppväxt, ett fokus som i mycket saknats i tidigare forskning. Om forskare undersökt hbtq-föräldrars lämplighet, deras relation till omvärlden, hur barnen klarar sig socialt och så vidare, är det helt enkelt få studier som intresserat sig för barnens egna berättelser. Avhandlingens styrka ligger också i de långa återgivningarna från intervjupersonerna. Så handlar exempelvis det första empiriska kapitlet om föräldrarnas olikartade komma-ut-processer - upplevda från barnens synvinkel. Det visar sig nämligen att detta är ett viktigt identifieringsmoment som regnbågsbarn, det är ju i denna stund de blir just regnbågsbarn, liksom en central omständighet som kommer att forma deras uppväxtvillkor framöver. Där är Maja, vars pappa introducerar en man i familjens liv när hon själv är i artonårsåldern - en ny person som också efter hand kom att ha en kärleksfull relation med hennes mamma. Där är Rut, vars pappa berättar för den trettonåriga dottern att han vill leva med män, men att hon aldrig får berätta att han har en pojkvän. Och där är Mia, vars mamma börjar leva allt längre perioder med sin flickvän i en annan stad, utan att maken eller barnen vet vad som försiggår.

Nordéns utgångspunkt är att det inte automatiskt är ett problem att växa upp i en regnbågsfamilj, men att det potentiellt görs till en konfliktyta i privata och institutionella rum, som i familjen, i skolan och på fritiden. Med en teoriapparat hämtad från Judith Halberstam, Sara Ahmed och Kathryn Stockton, vill han ringa in den sorts mellanläge som upp- 
står när ett barn som själv inte nödvändigtvis identifierar sig som ickeheterosexuell lever under villkor som genererar andra erfarenheter än barn i en heterosexuell familjebildning. Att så att säga vara kulturellt queer, men potentiellt straight, att inneha en queer kompentens utan att för den skull nödvändigtvis vara queer. I Nordéns tappning formuleras denna specifika belägenhet som att leva enligt en diagonal livslinje, till skillnad från den vertikala (heteronormativa) eller horisontella (ickeheterosexuella).

Intervjupersonerna beskriver mycket riktigt hur de uppfinner olika strategier för att förhålla sig till föräldrarnas annorlundaskap. De förklarar och utbildar, för att göra sin livssituation begriplig för omvärlden. De bråkar, säger emot, konfronterar och i vissa fall bortser de ifrån och tränger undan homofobiska attityder och påhopp. De "outar" sin queera familj för andra, underkommunicerar eller överdriver. Inte minst tröstar de och ställer sina egna behov åt sidan.

Många av berättelserna vittnar om en alldeles särskild ensamhet. Inte något av regnbågsbarnen har kompisar i samma sits och de flesta verkar vilja skona sina föräldrar från den värsta sortens utsatthet. Sammantaget visar intervjupersonernas berättelser hur föräldrarnas queerhet inte görs, styrs av eller ens är en angelägenhet för en enskild person, utan snarare samskapas av alla medlemmar i familjen.

Regnbågsungar är bitvis en stark läsning - inte minst för Nordéns förmåga att på ett respektfullt sätt närma sig både forskningsfrågor och intervjupersoner. Däremot är den onödigt teoretiskt framtung, för att inte säga snårig. Jag kommer exempelvis på mig själv med att fundera över om den omfattande genomgången av diskursanalys, med vidhängande begreppsapparat, egentligen behövs för analyserna av intervjumaterialet. En liknande tendens finns i det ymniga användandet av akademiska begrepp. Nordén hade lika gärna (eller ännu hellre) kunnat nöja sig med ett eller två välmotiverade begrepp i stället för tio som det inte är helt lätt att greppa skillnaden mellan.

En annan invändning, mer i form av reflektion än kritik, rör metodologi och reflexivitet. Avhandlingen bygger som sagt på berättelser, inhämtade i nutid, som beskriver tiden innan den nya öppenheten för- 
ändrade villkoren för queer reproduktion och föräldraskap. Detta betyder att intervjupersonerna anlägger en nutidsblick på dåtiden - något som hade varit spännande och förmodligen fruktbart att fundera några extra varv kring. Föräldrar som lever dolt, hemlighåller sina nära relationer och inte kommer på tanken att informera och hjälpa barnet att berätta för omgivningen om sin familjebild framstår i ett nutida raster som ytterst beklagliga, eller till och med obegripliga. I en tid då öppenhet varken var påbjuden eller önskvärd, då homosex var en privatsak och homosexuella officiellt inte hade barn, var det kanske snarare en rimlig överlevnadsstrategi. Framför allt var det inte nödvändigtvis något som det dåtida barnet upplevde med nutidens beklagande blick. Detta - den nutida blickens betydelse för de historier som berättas - hade helt enkelt varit både empiriskt och teoretiskt intressant att dröja vid ytterligare. Inte minst hade det gett läsaren fler möjliga nycklar till vad de senaste decenniernas samhällsförändringar egentligen betytt för barn som, liksom Nordén belyser, befinner sig i det mellanläge som en diagonal livslinje innebär, det vill säga regnbågsungar. 